\title{
Effect of heat treatment of milk on the physicochemical, microbiological and sensory characteristics of white cheese (Gibna bayda)
}

\author{
Mohamed Osman Mohamed Abdalla ${ }^{1,{ }^{*}}$ and Hanaa Mohammed Abbas Salih ${ }^{2}$ \\ ${ }^{1}$ Department of Biology, Faculty of Science and Arts, Al-Makhwah 65931, Al-Baha University, Saudi Arabia. \\ 2 Dryland Research Center (DLRC), Agriculture Research Corporation (ARC), Khartoum, Sudan.
}

Publication history: Received on 01 June 2020; revised on 06 June 2020; accepted on 08 June 2020

Article DOI: https://doi.org/10.30574/gscarr.2020.3.3.0044

\begin{abstract}
This study was conducted to determine the effect of heat treatment of milk on the physicochemical, microbiological, and sensory characteristics of white cheese (Gibna bayda). The cheese was made from raw warmed $\left(45^{\circ} \mathrm{C}\right)$ milk (T1) and heat-treated $\left(72{ }^{\circ} \mathrm{C} / 1 \mathrm{~min}\right)$ milk (T2) to which the starter culture $(2 \% \mathrm{w} / \mathrm{w})$, sodium chloride $(2 \% \mathrm{w} / \mathrm{w})$ and $\mathrm{CaCl} 2$ $(0.02 \% \mathrm{w} / \mathrm{w})$ were added. After manufacture, cheese was preserved at $5{ }^{\circ} \mathrm{C}$ for 45 days and subjected to physicochemical, microbiological, and sensory analysis. The results revealed that $\mathrm{T} 2$ had longer coagulation time (75.5 min) and higher cheese yield $(17.1 \mathrm{~kg} / 100 \mathrm{~L})$ compared to T1. Fat (25.28\%), moisture (55.70\%), and ash (6.40\%) contents were higher in T1, while protein (18.51\%), total solids (47.49\%) contents, and acidity $(0.56 \%)$ were high in T2. Total viable bacteria [TVB] ( $\left.\log _{10} 6.64 \mathrm{cfu} / \mathrm{gm}\right)$, Staphylococcus aureus $\left(\log _{10} 1.88 \mathrm{cfu} / \mathrm{gm}\right)$ and yeasts and moulds $\left(\log _{10} 5.53 \mathrm{cfu} / \mathrm{gm}\right)$ counts were high in T1, while Escherichia coli count was $\log _{10}<1.0 \mathrm{cfu} / \mathrm{gm}$ in both treatments. T1 scored better in taste (2.43), body (2.26), and overall acceptability (2.79), while T2 scored better in colour (3.44), flavour (2.79), and T2 cheese was slightly salty (1.45) than T1 cheese. The study concluded that heat treatment of milk improved some physicochemical and sensory characteristics of cheese, and heat-treated milk cheese was safer for human consumption than raw milk cheese.
\end{abstract}

Keywords: Gibna bayda; Heat treatment; Physicochemical; Microbiological; Sensory

\section{Introduction}

Cheese is the ripened or unripened soft, semi-hard, hard, or extra-hard product, in which the whey protein/casein ratio does not exceed that of milk, obtained by coagulating fully or partially the protein of milk, skimmed milk, partly skimmed milk, cream, whey cream or buttermilk, or a combination of these materials [1]. Cheese is one of the most common milk products produced by raw or pasteurized milk [2], and cheese making is the main method of preservation of milk in Sudan, especially during the rainy season when plenty of milk is available [3].

White cheese is the major cheese in Sudan [4], and it varies in composition, texture, colour, taste, and flavour due to milk composition, production methods, microbial flora, packaging type and microbial activity during the ripening [5]. It is unique among cheese varieties in its high concentration of table salt which is added to the milk before processing, with no starter culture added and only natural lactic acid bacteria of the raw milk carry the fermentation process required for cheese maturation $[6,7]$.

Heat treatment has become the most important part of milk processing representing the common practice of inhibiting the microbial growth in milk [8]. Despite developments in alternative technologies such as high-pressure processing and pulsed electric field technology for the destruction of microorganisms, heat treatment remains the method of choice in the dairy sector [9]. Heat-treated milk at higher temperatures shows longer coagulation times and forms weaker and

\footnotetext{
${ }^{*}$ Corresponding author: Mohamed Osman Mohamed Abdalla
} 
finer curd that retains more water, and these effects arise from the formation of complexes between denatured whey proteins and micellar $\kappa$-casein, leading to alteration of the surface characteristics and interactions of casein micelles [10]. Heat treatment of milk before cheese-making is not only an effective way of preventing the harmful effect of microorganisms but also causes changes in physicochemical properties of milk components which eventually lead to variations in the quality characteristics of cheese [11]. Compositional properties such as ash, acidity, and protein of the white cheeses are significantly affected by the heat treatment of milk, while fat content was not affected [12].

The sensory quality of the cheese is influenced by a heat treatment that induces changes in the physicochemical properties of milk components [11]. It is important to investigate the possibility of improving the properties of Sudanese white cheese, by changing the manufacturing processes through the introduction of pasteurization and the use of starter cultures. Hence, this study was conducted to study the effect of the heat treatment of milk on the physicochemical, microbiological, and sensory characteristics of white cheese (Gibna bayda).

\section{Material and methods}

\subsection{Materials}

Fresh raw cow milk was obtained from Sudan University farm at Kuku, Khartoum North, Sudan. Rennet powder and DVS starter culture (1:1 combination of Lactobacillus bulgaricus and Streptococcus thermophilus) were obtained from Chris Hansen's Laboratory (Denmark) and salt was purchased from the local market.

\subsection{Cheese manufacture}

Two treatments were prepared as follows: In the first treatment, the milk was only warmed to $45^{\circ} \mathrm{C}$ [T1], while in the second treatment, the milk was heat-treated $\left(72{ }^{\circ} \mathrm{C} / 1 \mathrm{~min}\right)$ followed by cooling to $45^{\circ} \mathrm{C}$ [T2]. The starter culture $(2 \%$ $\mathrm{w} / \mathrm{w})$, sodium chloride $(2 \% \mathrm{w} / \mathrm{w})$ and $\mathrm{CaCl}_{2}(0.02 \% \mathrm{w} / \mathrm{w})$ were added to both treatments. The milk was left undisturbed for $30 \mathrm{~min}$ to develop acidity, then the temperature was adjusted to $40{ }^{\circ} \mathrm{C}$, followed by the addition of rennet $(1.3 \mathrm{~g} / 50 \mathrm{~L}$ milk). Milk was stirred for $5 \mathrm{~min}$ and left to develop a curd, and after coagulation, the curd was cut by a sterile stainless-steel knife and left for $5 \mathrm{~min}$ for whey separation, the whey was then collected for further use in preservation. The curd was transferred into clean wooden moulds lined with a clean sterile cloth and pressed overnight (1 kg weight). The next day, the curd was cut into cubes $(2.5 \times 2.5 \times 2.5 \mathrm{~cm})$, weighed and preserved in the heat-treated $\left(72{ }^{\circ} \mathrm{C} / 1 \mathrm{~min}\right)$ salted $(2 \% \mathrm{w} / \mathrm{w})$ whey for $24 \mathrm{~h}$. The cheese was then stored without whey at $5{ }^{\circ} \mathrm{C}$ for 45 days, and subjected to physicochemical, microbiological, and sensory analysis.

\subsection{Physicochemical analysis}

The fat content was determined by the Gerber method [13], while the protein content was determined by the Kjeldahl method [13] as nitrogen content, then the protein content was calculated as follows:

$$
\begin{aligned}
& \text { Nitrogen }(\%)=\frac{\mathrm{T} \times 0.1 \times 0.014 \times 20 \times 100}{\text { Weight of sample }} \\
& \text { Protein }(\%)=\quad \text { Nitrogen }(\%) \times 6.38
\end{aligned}
$$

Where:

$\mathrm{T}=$ Titration figure $(\mathrm{ml})$

$0.1=$ Normality of $\mathrm{HCl}$

$0.014=$ Atomic weight of nitrogen $/ 1000$

$20=$ Dilution factor

The total solids content was determined according to the modified method of AOAC [13] by forced air oven drying at $100{ }^{\circ} \mathrm{C}$ for $3 \mathrm{~h}$ followed by cooling and weighing, and the weight of the sample after drying was divided by the weight of the original sample followed by multiplying by 100 . The ash content was determined by incinerating the sample in a muffle furnace at $550^{\circ} \mathrm{C}$ for $2 \mathrm{~h}$ followed by cooling and weighing, and the weight of the material left after incineration of the organic matter was then divided by the weight of the original sample and multiplied by 100 to get the ash content 
[13]. The titratable acidity was determined by titrating the sample using $0.1 \mathrm{~N} \mathrm{NaOH}$ and the titration figure was divided by the weight of the original sample followed by multiplication by 4 to get the titratable acidity [13].

\subsection{Microbiological examination}

\subsubsection{Preparation of samples}

Eleven grams were weighed aseptically in a sterile blender jar, and $99 \mathrm{ml}$ of sterile peptone water were added and blended for 2 min to make $10^{-1}$ dilution. Tenfold dilution was made up to $10^{-8}$ using a sterile peptone water [14].

\subsubsection{Total viable bacterial count [TVBC]}

Plate count agar medium (Himedia) was used for the enumeration of total viable bacteria [15]. Sample decimal dilution $(1 \mathrm{ml})$ was transferred into Petri dishes in duplicate followed by the addition of 18-20 ml melted and cooled medium $\left(45^{\circ} \mathrm{C}\right)$, mixed thoroughly by rotating the dishes firstly in one direction and then in the opposite direction. The inoculated plates were incubated at $37^{\circ} \mathrm{C}$ for $48 \mathrm{~h}$. Colonies of each plate were counted with a colony counter and TVBC was calculated as colony-forming units per gram of the sample (cfu/gm).

\subsubsection{S. aureus count}

Mannitol salt agar medium (Micro master) was used for the enumeration of S. aureus. Sample decimal dilutions (0.1 $\mathrm{ml}$ ) were transferred onto a pre-solidified medium and spread plated using a sterile glass rod. The plates were incubated in an inverted position at $37^{\circ} \mathrm{C}$ for $48 \mathrm{~h}$. Bright yellow colonies were recognized as S. aureus. Colonies were counted with a colony counter and regarded as colony-forming units per gram of the sample (cfu/gm) [16].

\subsubsection{E. coli count}

Brilliant green lactose bile (BGB) broth (Merck, 736) and peptone water (Himedia, M028) were used for the enumeration of $E$. coli using the most probable number technique [17]. Positive MacConkey broth tubes in total coliform counts were gently agitated and one loopful from each tube was transferred to a tube of BGB broth and another loopful to a tube of peptone water. Both tubes were incubated at $44.5^{\circ} \mathrm{C}$ for $24-48 \mathrm{~h}$, after which 0.2 ml of Kovac's reagent was added, shaken and left to stand for $10 \mathrm{~min}$ for indole production. Tubes of BGB broth were examined for turbidity and gas production in Durham tubes. Positive results were indicated for the presence of $E$. coli and used for further confirmation by streaking a loopful from each tube on Eosin methylene blue agar (EMB) for identification of colonies which show a nucleated dark center with or without metallic sheen which are characteristic features of $E$. coli in the medium. The isolates were further characterized by biochemical tests according to Barrow and Feltham [18]. Special attention was paid to the pattern of reactions of the organism in IMVIC tests. E. coli most probable number per ml of sample was calculated from the number of positive tubes of BGB broth and peptone water.

\subsubsection{Yeasts and moulds count}

Yeast extract agar medium (Biomark) was used for the enumeration of yeasts and moulds. Sample decimal dilutions $(0.1 \mathrm{ml})$ were transferred onto a pre-solidified medium and spread plated using a sterile glass rod [19]. The plates were incubated at $25^{\circ} \mathrm{C}$ for 5 days. Yeasts and moulds colonies were counted by a colony counter and recorded as colonyforming units per gram of the sample (cfu/gm) [23].

\subsection{Sensory evaluation}

A panel of ten untrained panelists were chosen and asked to judge on the quality of cheese (colour, flavour, body, taste, saltiness and overall acceptability) using an evaluation sheet, where colour ranged from $1=$ not acceptable to $4=$ acceptable; flavour 1 = bland to 4 = extremely intense; taste $1=$ absent to $4=$ excessive acid; body $1=$ smooth to $4=$ pasty; saltiness $1=$ moderate to 4 = too salty; overall acceptability 1 = unacceptable to 4 = acceptable [20].

\subsection{Statistical analysis}

The statistical analyses were performed using the Statistical Analysis Systems (SAS, ver. 9). Completely Randomized Design (CRD) was used to determine the effect of heat treatment of milk on the physicochemical, microbiological, and sensory characteristics of cheese. Mean separation was carried out using Duncan multiple range tests (P $\leq 0.05)$. 


\section{Results and discussion}

\subsection{Physicochemical characteristics of cheese milk}

The physicochemical characteristics of raw milk were $5.2 \%, 3.62 \%, 13 \%, 0.7 \%$ and $0.2 \%$ for fat, protein, total solids, ash contents, and acidity, respectively.

\subsection{Effect of heat treatment of milk on the coagulation time and cheese yield}

Coagulation time was $45 \mathrm{~min}$, and $75.5 \mathrm{~min}$ for T1 and T2, respectively, while cheese yield was $12.1 \mathrm{~kg} / 100 \mathrm{~L}$ and 17.1 $\mathrm{kg} / 100 \mathrm{~L}$ for T1 and T2, respectively (Table 1). Cheese yield is influenced by cheese-making processes such as cold storage of milk, heat treatment, standardization, coagulation, curd cutting and cooking, draining, pressing, and salting or ripening [21]. The result of coagulation time is consistent with Singh and Waungana [22] who found that milk heattreated at higher temperatures shows longer coagulation times and forms weaker and finer curd that retains more water, and these effects are considered to arise mainly from the formation of complexes between denatured whey proteins and micellar $\kappa$-casein, which subsequently modifies the surface characteristics and interactions of casein micelles [22]. Ismail et al. [23] reported that heating cow's and buffaloe's milk to $85{ }^{\circ} \mathrm{C} / 15$ sec increased rennet coagulation time and decreased curd tension and syneresis values. The result of cheese yield is consistent with that of Aly and Galal [24] who noticed that the highest cheese yield was obtained in pasteurized milk cheese. This may be attributed to the effect of pasteurization on $\kappa$-casein forming a complex with $\beta$-lactoglobulin increasing clotting time and subsequent cheese yield [25].

Table 1 Effect of heat treatment of cheese milk on the coagulation time and yield of white cheese.

\begin{tabular}{lll}
\hline Treatment & Coagulation time (min) & Cheese yield $(\mathbf{k g} / \mathbf{1 0 0} \mathbf{~ L )}$ \\
\hline $\mathrm{T} 1$ & 45 & 12.1 \\
$\mathrm{~T} 2$ & 75.5 & 17.1 \\
\hline & $\mathrm{T} 1$ = Raw milk cheese; $\mathrm{T} 2$ = Heat-treated milk cheese
\end{tabular}

\subsection{Effect of heat treatment of milk on the physicochemical characteristics of white cheese}

Physicochemical characteristics of white cheese as affected by heat treatment of milk are presented in Table 2 . Total solids and moisture contents were significantly $(\mathrm{P}<0.001)$ affected by heat treatment of milk, while fat, protein, ash contents, and acidity were not. The total solids content was significantly higher (47.49\%) in T2 cheese compared to T1 cheese (44.28\%). The results of protein, ash contents and acidity are in agreement with the findings of Mohamed and El Zubeir [26], while the results of total solids and fat contents are not. The result of total solids content is in line with Zeng et al. [27] and ElZubeir and Hashim [28] who found the higher total solids content being in heat-treated milk cheese. This could be due to the heat treatment of milk preventing losses of milk solids during storage [29]. Moisture content was significantly higher (55.70\%) in T1 cheese, and this result is in disagreement with that of Aly and Galal [24] who found that heat-treated and pasteurized milk cheeses revealed higher moisture than raw milk cheese. The ash content was insignificantly higher $(6.40 \%)$ in $\mathrm{T} 1$ cheese, a result which is consistent with the results of Abdalla and Ahmed [12] and Ocak et al. [30] who found that the ash content of raw milk cheese was higher than heat-treated milk cheese. Although the fat content was not significantly $(\mathrm{P}>0.05)$ affected by the heat treatment of milk, the slightly higher content was in T1 cheese (25.28\%). These results are in line with the findings of Abdalla and Ahmed [12] and Lau et al. [31] who reported that pasteurization has no effect on the recovery of fat in cheese, and in agreement with Aly and Galal [24] who reported that the fat content was slightly lower in heat- treated and pasteurized milk cheeses than in raw milk cheese. 
Table 2 Effect of heat treatment of milk on the physicochemical characteristics of white cheese (Gibna bayda).

\begin{tabular}{lllll}
\hline \multirow{2}{*}{$\begin{array}{l}\text { Physiochemical } \\
\text { characteristics (\%) }\end{array}$} & \multicolumn{2}{l}{ Type of cheese } & SE & SL \\
\cline { 2 - 4 } & T1 & T2 & 0.360 & NS \\
\hline Fat & $25.28^{\mathrm{a}}$ & $24.30^{\mathrm{a}}$ & 0.565 & $\mathrm{NS}$ \\
Protein & $18.21^{\mathrm{a}}$ & $18.51^{\mathrm{a}}$ & 0.584 & $* * *$ \\
Total solids & $44.28^{\mathrm{b}}$ & $47.49^{\mathrm{a}}$ & 0.570 & $* * *$ \\
Moisture & $55.70^{\mathrm{a}}$ & $53.44^{\mathrm{b}}$ & 0.172 & $\mathrm{NS}$ \\
Ash & $6.40^{\mathrm{a}}$ & $6.33^{\mathrm{a}}$ & 0.004 & $\mathrm{NS}$ \\
Acidity & $0.55^{\mathrm{a}}$ & $0.56^{\mathrm{a}}$ & \multicolumn{2}{c}{} \\
\hline \multicolumn{2}{c}{$\begin{array}{l}\text { Means in the same row bearing similar superscripts are not significantly different (P>0.05) } \\
* * *\end{array}=\mathrm{P}<0.001 ;$ NS $=$ Not significant; SL = Significance level; SE $=$ Standard error of means }
\end{tabular}

Protein content was not significantly $(\mathrm{P}>0.05)$ affected by heat treatment, although higher content $(18.51 \%)$ was reported in T2 cheese. Similar results were reported by Abdalla and Ahmed [12] and Ocak et al. [30]. Acidity was not significantly $(\mathrm{P}>0.05)$ affected by heat treatment, although the slightly higher value $(0.56 \%)$ was in T2 cheese. Warsama et al. [32] reported that the possibility of improving the properties of Sudanese white cheese, particularly through modifications of the manufacturing processes such as the introduction of pasteurization and the use of starter cultures, need to be examined, and that the compositional properties such as ash, acidity, and protein of the white cheeses were significantly affected by heat treatment of milk, while fat content was not [12]. Fajardo et al. [33] reported no significant differences in the physicochemical properties $(\mathrm{pH}$, acidity, humidity, protein, fat) of cheese manufactured from pasteurized milk with Lactococcus lactis and Lactococcus cremoris compared with the traditionally manufactured Costeño cheese (control).

\subsection{Effect of heat treatment of milk on the microbiological characteristics of white cheese}

Microbiological characteristics ( $\log _{10} \mathrm{cfu} / \mathrm{gm}$ ) of white cheese as affected by heat treatment of milk is presented in Table 3. S. aureus and yeasts and moulds counts were significantly $(\mathrm{P}<0.001)$ affected by heat treatment of cheese milk being high in T1 cheese $\left(\log _{10} 1.88 \mathrm{cfu} / \mathrm{gm}\right.$, and $\log _{10} 5.53 \mathrm{cfu} / \mathrm{gm}$, respectively), while TVB and $E$. coli counts were not, although the slightly high count of TVB was in T1 $\left(\log _{10} 6.64 \mathrm{cfu} / \mathrm{gm}\right)$, and $E$. coli count was $\log _{10}<1.0 \mathrm{cfu} / \mathrm{gm}$ for T1 and T2. The high microbial content of soft white cheese reflects the poor hygienic conditions during cheese production, lack of cooling and heat treatment, while the contamination of cheese with $S$. aureus suggests inadequate care during processing, and such foods certainly pose a danger to consumers [34]. This result is in agreement with Johnson et al. [35] who found that the heat treatment at $68^{\circ} \mathrm{C}$ significantly reduced $S$. aureus count. The result of TVBC is in line with Hadi-Sulieman [36] who reported that Jibna Beyda made from raw milk was high in TVBC compared to that made from heat-treated milk. E. coli count was not significantly $(\mathrm{P}>0.05)$ affected by heat treatment. The appearance of $E$. coli in heat-treated milk cheese could be due to contamination during the processing of cheese or post pasteurization contamination [37]. The results of yeasts and moulds count are in line with the results of Aly and Galal [24] who found that moulds and yeasts count was significantly $(\mathrm{P}<0.01)$ higher in cheese made from raw milk in comparison with the heat-treated milk cheese. Heikal et al. [38] analyzed 150 samples of traditional white cheese made from raw milk, and reported high microbial counts of $\log _{10} 6.80 \mathrm{cfu} / \mathrm{gm}, \log _{10} 4.41 \mathrm{cfu} / \mathrm{gm}$ and $\log _{10} 4.37 \mathrm{cfu} / \mathrm{gm}$ for total aerobes, coliforms, and staphylococci, respectively, while E. coli, Salmonella spp. and S. aureus were found in $26.7 \%, 6.7 \%$, and $6.7 \%$ of examined samples, respectively. Therefore, they suggested that the raw milk and the equipment were the potential sources of contamination during cheese manufacture. However, pasteurized milk cheese samples collected from different processing plants located in Western Ae-gean region of Turkey were reported to contain $\log _{10} 9.43 \mathrm{cfu} / \mathrm{gm}$ and $\log _{10} 4.87 \mathrm{cfu} / \mathrm{gm}$ for TVB and $S$. aureus counts, respectively, while E. coli and L. monocytogenes were determined in $26.6 \%$ of the samples [37]. Mohamed and El Zubeir [26] outlined that there was highly significant $(\mathrm{P} \leq 0.01)$ differences in $S$. aureus and coliform bacteria counts in cheese samples collected from traditional $(13 ; 65 \%)$ and modern dairy plants $(0 \%)$, while yeasts and moulds were not detected in cheese samples from both processors, therefore, they concluded that Sudanese white cheese produced in modern dairy factories is safer than that produced traditionally. Pasteurized milk cheese samples had significantly lower levels of enterococci and enterobacteria than raw milk cheese 
Table 3 Effect of heat treatment of milk on the microbiological characteristics $\left(\log _{10} \mathrm{cfu} / \mathrm{gm}\right)$ of white cheese (Gibna bayda).

\begin{tabular}{|c|c|c|c|c|}
\hline \multirow{2}{*}{$\begin{array}{l}\text { Microbiological } \\
\text { characteristics }\end{array}$} & \multicolumn{2}{|c|}{ Type of cheese } & \multirow{2}{*}{ SE } & \multirow{2}{*}{ SL } \\
\hline & $\mathbf{T 1}$ & T2 & & \\
\hline TVB & $6.64^{\mathrm{a}}$ & $6.61^{\mathrm{a}}$ & 0.005 & NS \\
\hline S. aureus & $1.88^{\mathrm{a}}$ & $0.76^{\mathrm{b}}$ & 0.122 & $* * *$ \\
\hline E. coli & $<0.10^{\mathrm{a}}$ & $<0.10^{a}$ & 0.115 & NS \\
\hline Yeasts and moulds & $5.53^{\mathrm{a}}$ & $4.85^{\mathrm{b}}$ & 0.114 & $* * *$ \\
\hline
\end{tabular}

samples, while yeasts grew at similar levels during the storage at $4{ }^{\circ} \mathrm{C}$, and all cheese samples were free of Salmonella and Listeria monocytogenes [39]. Coagulase-positive staphylococci exceeded the 5-log safety threshold in fresh raw milk cheese samples, whereas they were suppressed in all pasteurized milk cheese samples [39]. Pyz-Łukasik et al. [40] reported that the levels of coliform bacteria, E. coli, and coagulase-positive Staphylococcus in the traditional short and long-ripened cheeses made with raw and pasteurized cow's milk indicated insufficient hygiene procedures during the production and that the cheeses did not comply with the criteria for food safety and hygiene according to the legislation.

\subsection{Effect of heat treatment of milk on the sensory characteristics of white cheese}

Sensory characteristics of white cheese as affected by the heat treatment of milk are presented in Table 4. The colour (3.44) and flavour (2.79) scores were significantly higher in T2 cheese, while the overall acceptability (2.79) score was significantly $(\mathrm{P}<0.01)$ higher in $\mathrm{T} 1$ cheese, and taste $(2.43)$ and body $(2.26)$ scores were not significantly affected, although the higher scores were in T1 cheese, and T2 cheese was slightly (1.45) salty although the difference was not significant. The result of the body is in disagreement with that of El Zubeir and Hashim [28] who found that the heattreated milk cheese received a higher score for texture in comparison with raw cheese milk.

Table 4 Effect of heat treatment of milk on the sensory characteristics of white cheese (Gibna bayda).

\begin{tabular}{|c|c|c|c|c|}
\hline \multirow{2}{*}{$\begin{array}{l}\text { Sensory } \\
\text { characteristics }\end{array}$} & \multicolumn{2}{|c|}{ Type of cheese } & \multirow{2}{*}{ SE } & \multirow{2}{*}{ SL } \\
\hline & T1 & $\mathbf{T} 2$ & & \\
\hline Colour & $3.16^{\mathrm{b}}$ & $3.44^{\mathrm{a}}$ & 0.005 & $* * *$ \\
\hline Flavour & $2.53^{\mathrm{b}}$ & $2.79^{a}$ & 0.006 & $* *$ \\
\hline Taste & $2.43^{\mathrm{a}}$ & $2.30^{\mathrm{a}}$ & 0.006 & NS \\
\hline Body & $2.26^{\mathrm{a}}$ & $2.18^{\mathrm{a}}$ & 0.007 & NS \\
\hline Saltiness & $1.44^{\mathrm{a}}$ & $1.45^{\mathrm{a}}$ & 0.004 & NS \\
\hline Overall acceptability & $2.79^{\mathrm{a}}$ & $2.48^{\mathrm{b}}$ & 0.007 & $* *$ \\
\hline
\end{tabular}

The result of colour is in line with Frau et al. [10] who found that cheese made with pasteurized milk at $75^{\circ} \mathrm{C}$ had a higher score in visual appearance. The result of flavour is in agreement with Gosh and Singh [41] who found that cheese produced from pasteurized milk had a better flavour than that produced from raw milk. The taste score was not significantly affected by the heat treatment of cheese milk. Cheese made from raw milk scored much higher in flavour compared to thermized and pasteurized milk cheeses, while thermized and pasteurized milk cheeses were characterized by a more compact body and smoother texture [42]. Aroma scores of raw and heat-treated milk cheeses made with starter were not significantly different, and the panelists scored cheeses made from raw milk without starter as the best in body and texture [43]. Sensorial analysis of Costeño cheese showed a greater preference $(\mathrm{P}<0.05)$ in cheese manufactured pasteurized milk with Lactococcus lactis and Lactococcus cremoris compared to other types [33]. 


\section{Conclusion}

Heat treatment of milk positively affected the coagulation time and yield of cheese, while the protein, total solids content, and acidity were improved by the heat treatment of milk. The microbiological characteristics of cheese were improved by heating milk for cheese making since the counts of TVB, S. aureus, and yeasts and moulds significantly reduced in cheese made by heat-treated milk and the $E$. coli count was reduced to $\log _{10}<1.0 \mathrm{cfu} / \mathrm{gm}$. Heat treatment of milk improved the sensory properties of cheese except for overall acceptability. Therefore, milk heat treatment for making white cheese leads to a safer product with better quality from a physicochemical and sensory point of view.

\section{Compliance with ethical standards}

\section{Acknowledgments}

The authors acknowledge the cooperation of the administration in the dairy farm from which raw milk was collected, and the staff of the Department of Dairy production, Faculty of Animal Production, where the research was conducted.

\section{Disclosure of conflict of interest}

The authors declare no conflict of interest.

\section{References}

[1] Bezie A. (2019). The effect of different heat treatment on the nutritional value of milk and milk products and shelf-Life of milk products. A Review. Dairy and Veterinary Science Journal, 11(5), 555822.

[2] Mahieddine B, Nesrine F, Farah M, Dalichaouche N, Feknous I, Touafchia L, Metlaoui N and Zenki R. (2017). Characterization of goat milk produced in the Northeast Algeria region. Fresh cheese making trial. Algerian Journal of Natural Products, 5(2), 492-506.

[3] ElOwni OAO and Hamid AIO. (2008). Effect of storage period on weight loss, chemical composition, microbiological and sensory characteristics of Sudanese white cheese (Gibna Badya), Pakistan Journal of Nutrition, 7(1), 75- 80.

[4] El-Hag FM, Bushara I, Ahmed MMM, Hag Mahmoud KE, Kheir MAM, Elbushra EO and Ahmed TK. (2014). Assessment of rural dairy products in North Kordofan state, Sudan. Global Journal of Animal Scientific Research, 2(1), 1-9.

[5] Mustafa AW, Sulieman EA, Abdelgadir SW and Elkhalifa AE. (2013). Microbiological characteristics of the white cheese produced at household level in Duwaim area, White Nile State, Sudan. University of Bakht Alruda Scientific Journal, (7), 165-173.

[6] Abdalla OM, Christen GL and Davidson PM. (1993). Chemical composition of and Listeria monocytogenes survival in white pickled cheese. Journal of Food Protection, 56, 841-846.

[7] Abdelaziz OAE and Hamid AIO. (2013). Characterization of free fatty acids contents of Sudanese white cheese during storage. Journal of Advanced Scientific Research, 4(1), 22-26.

[8] Ritota M, Gabriella M, Costanzo D, Mattera M and Manzi P. (2017). New trends for the evaluation of heat treatments of milk. Journal of Analytical Methods in Chemistry, Volume 2017, Article ID 1864832, 12.

[9] Deeth H and Smithers G. (2018). Heat treatment of milk - Overview. IDF Factsheet 001/201802.https://www.fil-idf.org/wp-content/uploads/2018/02/Factsheet-01_Heat-treatment-1-1.pdf. Access date: $26 / 5 / 2020$.

[10] Frau F, de Valdez GF and Pece N. (2014). Effect of pasteurization temperature, starter culture, and incubation temperature on the physicochemical properties, yield, rheology, and sensory characteristics of spreadable goat cheese. Journal of Food Processing, Volume 2014, Article ID 705746, 8 pages.

[11] Atasoy F, Atilla Y, Huseyin T and Barbaros O. (2008). Effects of heat treatment and starter culture on the properties of traditional Urfa cheeses (a white-brined Turkish cheese) produced from bovine milk. Food Control, $19,278-285$.

[12] Abdalla MOM and Ahmed O. (2010). Effect of heat treatment, level of sodium chloride, calcium chloride on the chemical composition of white cheese. Research Journal of Animal and Veterinary Sciences, 5, 69-72. 
[13] AOAC. (2001). Official Methods of Analysis of AOAC International. 17th Edition. Association of Official Analytical Chemists International, Gaitherburg, MD, USA, Official Methods, 920.124, 926.08, 955.30.

[14] Harrigan WF. (1998). Laboratory methods in food microbiology, Third edition. Academic Press, London, UK, 202245.

[15] Houghtby AG, Maturin LJ and Koenig KE. (1992). Microbiological count methods. In: Marshal RT (Ed), Standard Methods for the Examination of Dairy Products, 16th Edn. American Public Health Association, Washington, DC, USA, 213-246.

[16] Flowers SR, Andrews W, Donnelly CW and Koenig EK. (1992). Pathogens in Milk and Milk Products. In: Marshal RT (Ed), Standard Methods for the Examination of Dairy Products, 16th Edn. American Public Health Association, Washington, DC, USA, 103-212.

[17] Christen LG, Davidson PM, McAllister JS and Roth LA. (1992). Coliform and other indicator bacteria. In: Marshal RT (Ed), Standard Methods for the Examination of Dairy Products, 16th Edn. American Public Health Association, Washington, DC, USA, 247-269.

[18] Barrow GL and Feltham RKA. (1993). Cowan and Steel's Manual for the Identification of Medical Bacteria, Third edition. Cambridge University Press, Cambridge, UK, 21-48.

[19] Frank FJ, Christen LG and Bullerman LB. (1992). Tests for groups of microorganisms. In: Marshal RT (Ed), Standard Methods for the Examination of Dairy Products, 16th Edn. American Public Health Association, Washington, DC, USA, 271-286.

[20] Singh-Ackbarali D and Maharaj R. (2014). Sensory evaluation as a tool in determining acceptability of innovative products developed by undergraduate students in food science and technology at the University of Trinidad and Tobago. Journal of Curriculum and Teaching, 3(1), 10-27.

[21] Tadjine D, Boudalia S, Bousbia A, Khelifa R, Boudechiche LM, Tadjine A and Chemmam M. (2019). Pasteurization effects on yield and physicochemical parameters of cheese in cow and goat milk. Food Science and Technology Campinas. DOI: Dhttps://doi.org/10.1590/fst.13119.

[22] Singh H and Waungana A. (2001). Influence of heat treatment of milk on cheese making properties. International Dairy Journal, 11(4-7), 543-551.

[23] Ismail AM, Ismail MM and Hashem MI. (2004). Effect of some heat treatments on the quality of Edam cheese made from buffaloe's milk. The 9th Egyptian Conference for Dairy Science and Technology "Milk and Dairy Products for a Healthy Future" Cairo, Egypt, 9-11.

[24] Aly AS and Galal EA. (2002). Effect of milk pretreatment on the keeping quality of Domiati cheese. Pakistan Journal Nutrition, 1, 132-136.

[25] Girgis ES, Abd El-ghany IHI, Yousef LM and Mohamed LM. (1999). Effect of milk pretreatment and storage condition on the properties and keeping quality of Ras cheese. Egyptian Journal of Dairy Science, 27, 153-166.

[26] Mohamed OAE and El Zubeir IEM. (2018). Comparative study on chemical and microbiological properties of white cheese produced by traditional and modern factories. Annals. Food Science and Technology, 19(1), 111120 .

[27] Zeng SS, Soryal K, Fecadu B, Baha B and Pophamd T. (2007). Predictive formulae for goat cheese yield based on milk composition. Small Ruminant Research, 69, 180-186.

[28] ElZubeir MEI and Hashim AF. (2013). Effect of heating on chemical characteristics and acceptability of Sudanese white cheese made from goat's milk. Conference on International Research on Food Security, Natural Resource Management and Rural Development, 1-4.

[29] Abd El-Gawad MAM and Ahmed SN. (2011). Cheese yield as affected by some parameters. Review. Acta Scientiarum Polonorum Technologia Alimentaria, 10(2), 131-153.

[30] Ocak E, Andic S and Tuncturk Y. (2014). The effect of homogenization, $\mathrm{CaCl}_{2}$ addition and pasteurization on white cheese and whey composition. Yuzunco Yil Universitesi Journal of Agriculture Science, 24(1), 70-78.

[31] Lau KY, Barbano DM and Rasmussen RR. (1990). Influence of pasteurization and fat on nitrogen recovery and cheddar cheese yield. Journal of Dairy Science, 73(3), 561-570.

[32] Warsama LM, ElZubeir IEM and ElOwni OAO. (2006). Composition and hygienic quality of Sudanese white cheese in Khartoum North markets (Sudan). International Journal of Dairy Science, 1, 36-43. 
[33] Fajardo JGS, de la Ossa TIP and Hernández EJR. (2016).Effect of pasteurization and starter cultures on physicochemical and microbiological properties of Costeño cheese. Revista Facultad Nacional de Agronomía, 69(2), 8007-8014.

[34] Haddad MA and Yamani MI. (2017). Microbiological quality of soft white cheese produced traditionally in Jordan. Journal of Food Processing and Technology, 8, 706. doi: 10.4172/2157-7110.1000706.

[35] Johnson EA, Nelson JH and Johnson M. (1990). Microbiological safety of cheese made from heat-treated milk, Part II. Microbiology. Journal of Food Protection, 53, 519-540.

[36] Hadi-Suliman AMEL. (2007). Effect of pretreatment of milk quality characteristics of Jibna-beida (white cheese). International Journal of Food Engineering, 3, 1-11.

[37] Kizanlik PK and Göksoy EÖ. (2018). Microbiological quality evaluation of various types of cheese. Erciyes Üniv Vet Fak Derg, 15(2), 86-93.

[38] Heikal GI, Khater DF and Al-wakeel SA. (2014). Bacteriological hazard of white cheese processed in some small primitive plants (dairy shops) in Tanta city. Benha Veterinary Medical Journal, 26(1), 185-194.

[39] Pappa EC, Bontinis TG, Tasioula-Margari M and Samelis J. (2017). Microbial quality of and biochemical changes in fresh soft, acid-curd Xinotyri cheese made from raw or pasteurized goat's milk. Food Technology and Biotechnology, 55 (4), 496-510.

[40] Pyz-Łukasik R, Knysz P and Gondek M. (2018). Hygiene quality and consumer safety of traditional short- and long-ripened cheeses from Poland. Journal of Food Quality, Article ID 8732412, 7.

[41] Gosh BC and Singh S. (1990). Effect of heat treatment on the quality mozzarella cheese from buffalo milk. Journal of Food Science and Technology, 27(4), 218-220.

[42] Hammam ARA, Tammam AA and Abd EI-Rahlm AM. (2018). Effect of different beat treatments on the characteristics of Ras cheese during ripening. Egyptian Journal of Dairy Science, 46, 111-119.

[43] Aydemir 0 and Dervisoglu M. (2010). The effect of heat treatment and starter culture on colour intensity and sensory properties of Kulek cheese. International Journal of Dairy Technology, 63(4), 569-574.

\section{How to cite this article}

Abdalla Mohamed OM and Hanaa Mohammed AS. (2020). Effect of heat treatment of milk on the physicochemical, microbiological and sensory characteristics of white cheese (Gibna bayda). GSC Advanced Research and Reviews, 3(3), 20-28. 